\title{
Assessment of the impact of an overlying coal seam edge using seismic profiling of refracted $P$ - wave velocity
}

\author{
Zbigniew Szreder ${ }^{1}$ Maciej Barnaś2* \\ ${ }^{1}$ JSW S.A. KWK Budryk, 43-178 Ornontowice, Poland \\ ${ }^{2}$ Mineral and Energy Economy Research Institute, Polish Academy of Science, 31-261 Krakow, \\ Poland
}

\begin{abstract}
This paper presents the results of seismic profiling along the sidewalls of two headings of a longwall in a coal-seam at a depth of about 850 and 870 metres in a coal mine in the Upper Silesian Coal Basin, Poland. The seismic profiles were located in a zone of impact of the same overlying edge of the coal-seam located about $40 \mathrm{~m}$ above. This study was interesting from that point of view since there were no other geological and mining factors present which could disturb the impact of the coal seam edge. The profiling of refracted P-wave velocity changes was carried out according to the Dubinski method. This method is used for the assessment of relative stress in a coal seam in the side wall of the excavation. The results obtained on both seismic profiles are very similar, which demonstrates the small impact of the overlying edge of the coal seam in both headings of a longwall. It should be emphasised that at greater exploitation depths, the calculated reference velocity is less reliable than the measured reference velocity. Presumably, the method of calculating seismic anomaly requires updating under such conditions, but additional evidence should be collected.
\end{abstract}

\section{Introduction}

In underground coal mines, various types of hazards occur which affect the maintenance of the stability of excavations which are related to geological and mining factors [1-4]. Such hazards include various edges and remnants of already-exploited coal seams, which create excessive concentrations of stress in the rock mass and a simultaneously unfavourable impact on mining excavations [5-6]. Mining also causes the activation of faults, which creates concentrations of excessive stress [7-8]. The magnitude and extent of the impact of the unexploited edges and remnants of coal seams and activated faults can be measured using the seismic profiling method [3,9]. This method is used for the assessment of relative stress in the coal seam in the longwall side of the excavation. The results achieved by seismic profiling are particularly useful in qualitative assessments of the stability of supportexcavation systems and also rock bursts.

\footnotetext{
* Corresponding author: barnas@meeri.pl
} 
There are many methods for evaluating the impact of various types of geological and mining factors on the behaviour of the excavation e.g. convergence, various borehole measurements, pressure sensors installed in the elements of excavation support, and geophysical measurements [10-12]. For this purpose, various types of analytical and numerical calculations are also used [13-17]. Under the conditions in Polish hard coal mines the method of seismic profiling [3, 9, 18-20] is commonly used.

Seismic profiling has been used to evaluate the effectiveness of destressing blasting. Tor et al. [21] presented an example of the control of the effectiveness of destressing blasting using seismic profiling in the Jas-Mos coal mine in the region of the 22a longwall in the 510/1 coal seam. The results of profiling have also been used to define a more detailed location for subsequent blastings. The possibility of seismic interpretation was also demonstrated, enabling one to determine the width of the fracture zone along the side-wall of the excavation.

Studies were also made of the profiling of changes in the attenuation coefficient and Pwave velocity in the coal seam along the side-wall of the headings [18, 22-23]. Szreder and Pilecki [18] concluded that the attenuation coefficient is more sensitive to changes of stress and deformation in the coal-seam compared to changes of refracted P-wave velocity. The value of an attenuation coefficient can vary many times more than the value of the seismic wave velocity. This issue has significant implications in practice because $\mathrm{P}$-wave velocity increases are small at greater depths.

Seismic profiling in underground excavations was also carried out for different purposes in other geological conditions for example: in a salt body to estimate the width of the fracture zone in the side-walls of excavations [24] and also in tunnelling [25].

The paper presents the results of seismic profiling conducted in one of the hard coal mines in the Upper Silesian Coal Basin (USCB). The aim of these studies was to determine the anomalous changes in seismic P-wave velocity in the X0 coal seam in the sidewalls of A longwall headings, in the zone of impact of the overlying edge of the X1coal seam at depths of about $850 \mathrm{~m}$ and $870 \mathrm{~m}$. The edge of the X1 coal seam was located about $40 \mathrm{~m}$ above the $\mathrm{X} 0$ coal seam. This study was interesting from that point of view since there were no other geological and mining factors present that could disturb the impact of the coal seam edge.

\section{Theoretical assumptions of seismic profiling in coal seam}

The basic parameter calculated from seismic profiling in a coal seam is the velocity of a refracted P-wave. This is the velocity of a wave propagating along an excavation in an elasticity zone (not disturbed by excavation) on the border with a plasticity zone (disturbed by excavation). The border between the zones of elasticity and plasticity may be illustrated by the use of a Ladanyi model [26], under conditions of interaction of excavation support with the surrounding rock mass (Fig.1).

The maximum of circumferential stresses occurs in a zone of elasticity on the border with a zone of plasticity (Fig.1). It should be assumption that the most favourable conditions for the propagation of a refracted wave (Fig. 2) occur in this part of the zone of elasticity and changes of P-wave velocity can correlate with changes of stresses. In practice, the border between zones of elasticity and plasticity has a transitional character and the propagation of seismic waves is more complex. A complicated character of wave field is visible on seismograms. A significant influence on the distortion of the wave pattern is the intensely variable width of the zone of plasticity along the excavation (Fig. 3). The determination of the onset of the refracted wave and its amplitude is frequently hindered under these conditions. This is demonstrated by the unreal results of inversion modelling which are often observed during an interpretation of the measurements of seismic profiling. 


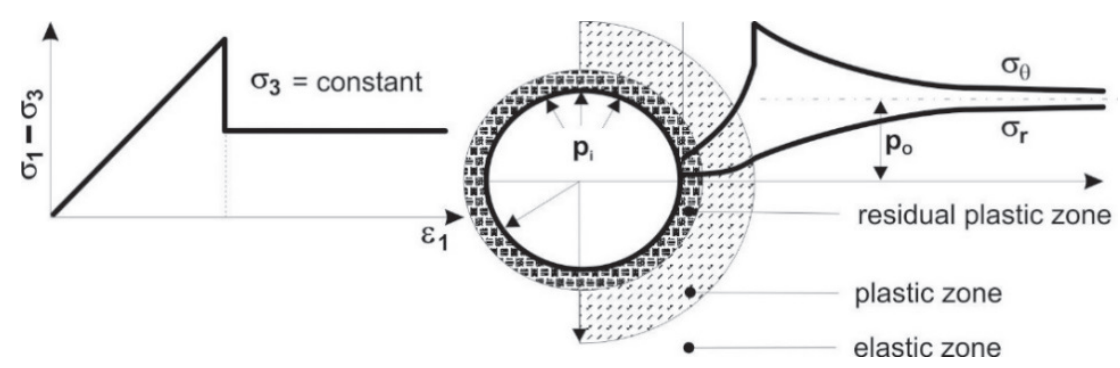

Fig. 1. Model of behaviour of a rock mass around an excavation on the basis of Ladanyi [26] $\sigma_{1}-$ major principal stress, $\sigma_{3}$ - minor principal stress, $\sigma_{\theta}$ - tangential stress, $\sigma_{r}$ - radial stress, $\varepsilon_{1}$ - major principal strain, $p_{o}-$ virgin stress, $p_{i}-$ lining load [18].

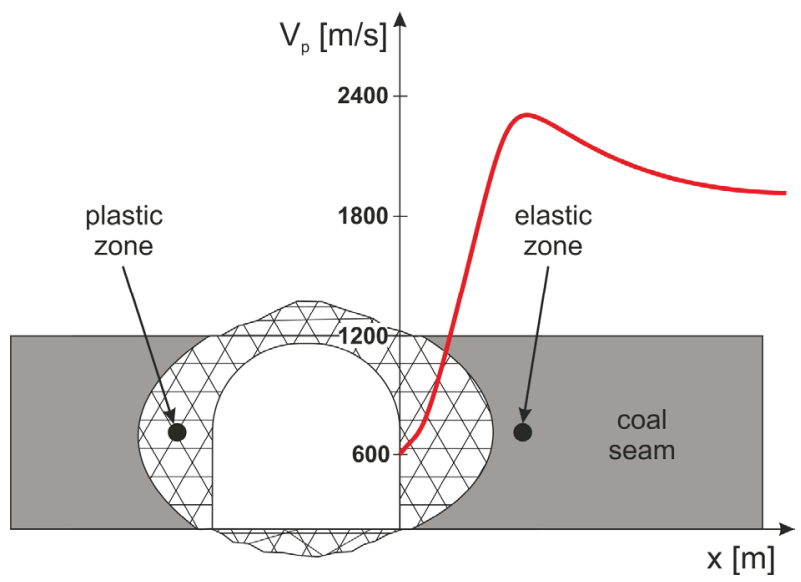

Fig. 2. An example of changes in P-wave velocity in the side-wall of the excavation [18].

The determination of the onset of a P-wave in a heterogenous medium is difficult due to the complicated wave field in a plasticity zone in close proximity to the sidewall of excavations. Many types of waves may form in such conditions: direct, reflected, diffracted, refracted also along the roof and floor of the coal seam or channel waves.

\section{Methodology}

Profiling of the refracted P-wave velocity is performed according to the Dubiński method [9] updated in work of Dubiński and Konopko [3]. In practice, interpretation of the profiling is carried out with the help of refraction algorithms for a two-layer model.

Depending on the conditions of refracted P-wave propagation in a coal-seam, the length of spread for 24 geophones may reach up to 115 metres adjusted to the energy of the wave source. The geophone interval should be assumed to be from 2 to 5 metres depending on the possibility of identifying refracted P-waves. The seismic wave is excited with the use of a stroke with a sledgehammer. For improvement of the signal to noise ratio, at least six fold stacking should be applied. The seismic records are legible even in longer sections in the case of a low level of seismic noise and high amplification in the test equipment of the order of over $100 \mathrm{~dB}$. The geophone may be installed in a different way, in addition to which the contact with the rock mass is to secure distinct and non-deformed onsets of refracted waves. The geophones are usually fixed on short anchors a few centimetres long in not intensively fractured and not separated fragments of hard coal. This ensures that the wave image is useful enough for an interpretation. The recording time and signal sampling have always to be tested 
in a specific investigation site. On the basis of previous experiments, one should select a sample interval of $0.125 \mathrm{~ms}$ and record length of $0.5 \mathrm{sec}$.

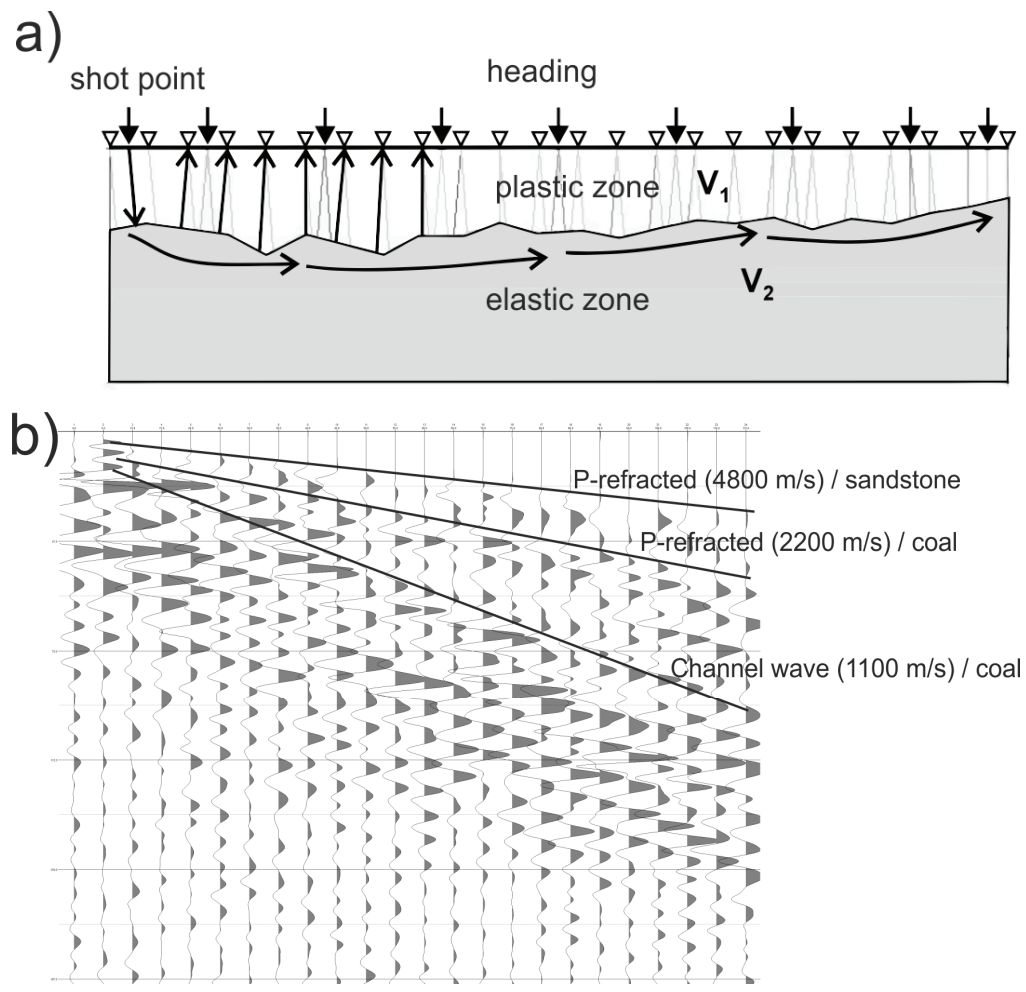

Fig. 3. Seismic profiling in a coal seam along an excavation side-wall: (a) refracted P-wave wave propagation (V2 velocity); (b) example of wave pattern [18].

In the interpretation stage, a two-layer model of a medium consisting of a fracture zone (plastic zone) and a solid zone (elastic zone) is assumed. The reciprocal travel times method is used to calculate the velocity model and width of the fracture zone. The velocity model is corrected by the reverse analysis method. By changing the position of the seismic boundaries of the model, the calculated hodographs are adjusted to the observations. The accuracy of the calculations is verified by minimising the average square error. Figure 4 shows the successive stages of seismic profiling.

In the studies, two modules of Geometrics SeisImager software were applied, Pickwin and Plotrefa, which are shown on the diagram in Figure 4. The Pickwin is used to identify the first breaks of P-wave. Due to an unfavourable signal-to-noise ratio and the complexity of the recorded waveform (interference of longitudinal and transverse waves), frequency filtering was applied in the Pickwin software. In the next stage, the results from Pickwin were used in the Plotrefa software for data interpretation, according to the procedures outlined in Figure 4. 


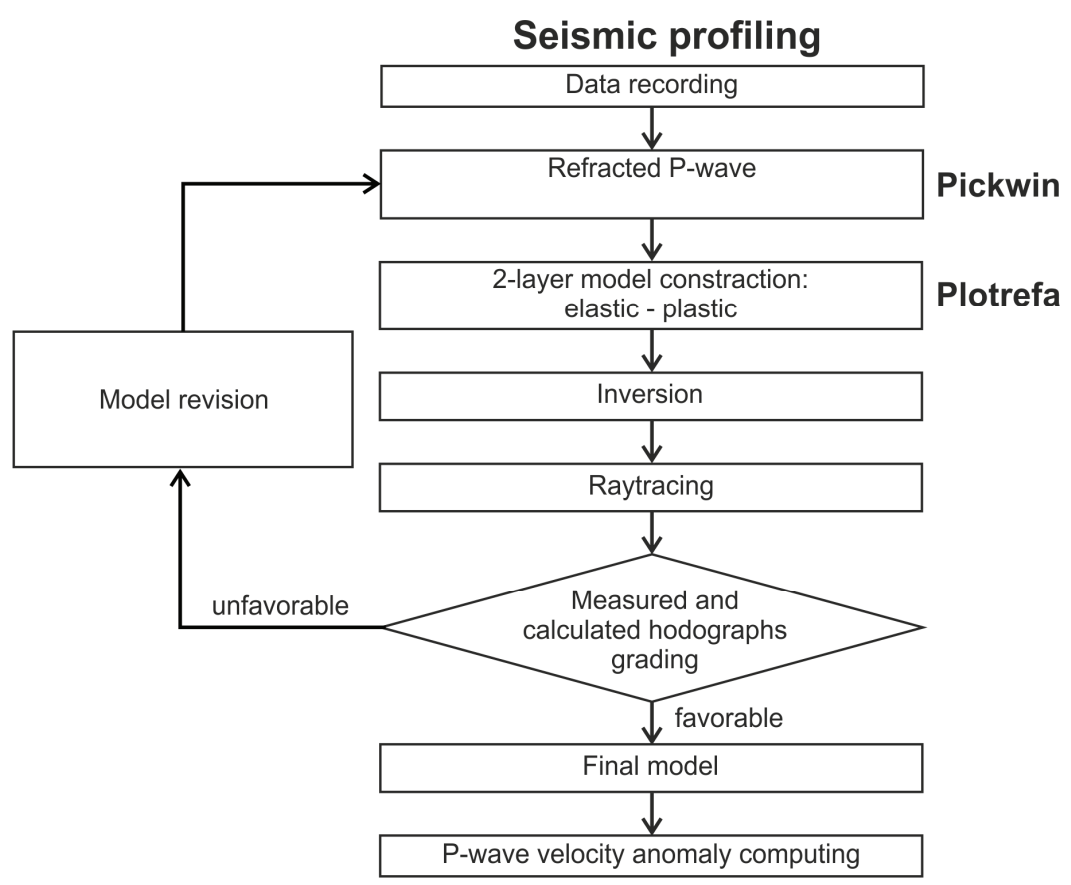

Fig. 4. Block diagram of seismic profiling in the mining excavation.

From this, the refracted P-wave velocity in the coal seam was calculated along the profile. In the final stage, velocity changes were compared with the reference velocity determined from the Dubinski empirical equation [3]:

$$
V_{p}^{0}=1200+4.83 H^{0,76}
$$

where:

$V_{p}^{0}-$ reference velocity $[\mathrm{m} / \mathrm{s}]$

$\mathrm{H}$ - depth of survey area $[\mathrm{m}]$.

The reference velocity $\mathrm{V}^{0}$ and the measured velocity $\mathrm{V}^{\mathrm{R}}$ were used to calculate the percentage anomaly $\mathrm{A}^{0}$ according to the formula:

$$
A^{0}=\frac{V^{R}-V_{p}^{0}}{V^{R}} \cdot 100 \%
$$

Sometimes, the anomaly used to be calculated on the basis of measured velocity in the undisturbed zone instead of using the calculated reference velocity. The calculated anomaly of the velocity is applied to evaluate the relative stress state based on the seismic scale, determined for USCB conditions (Table 1 and 2).

Table 1. Seismic scale of relative stress increase under USCB conditions [3].

\begin{tabular}{|c|c|c|c|}
\hline $\begin{array}{c}\text { Degree of relative } \\
\text { stress increase }\end{array}$ & $\begin{array}{c}\text { Scale of relative } \\
\text { stress increase }\end{array}$ & $\begin{array}{c}\text { Seismic anomaly } \\
{[\%]}\end{array}$ & $\begin{array}{c}\text { Probable increase } \\
\text { in relative stress } \\
{[\%]}\end{array}$ \\
\hline 0 & lack/very low & below 5 & below 20 \\
\hline 1 & low & $5-15$ & $20-60$ \\
\hline 2 & medium & $15-25$ & $60-140$ \\
\hline 3 & high & above 25 & above 140 \\
\hline
\end{tabular}


Table 2. Seismic scale of relative stress decrease under USCB conditions [3].

\begin{tabular}{|c|c|c|c|}
\hline $\begin{array}{c}\text { Degree of } \\
\text { stress decrease }\end{array}$ & $\begin{array}{c}\text { Scale of relative } \\
\text { stress decrease }\end{array}$ & $\begin{array}{c}\text { Seismic anomaly } \\
{[\%]}\end{array}$ & $\begin{array}{c}\text { Probable decrease } \\
\text { in relative stress } \\
{[\%]}\end{array}$ \\
\hline 0 & lack/very low & above -7.5 & below 25 \\
\hline 1 & low & $-7.5 \div-15$ & $25 \div 55$ \\
\hline 2 & medium & $-15 \div-25$ & $55 \div 80$ \\
\hline 3 & high & below -25 & above 80 \\
\hline
\end{tabular}

\section{Location and geological and mining conditions}

Seismic measurements were conducted in the region of a planned A longwall in the X0 coal seam (Figure 5a). The seismic profile I - I ' was carried out in the A1 heading at a depth of about $870 \mathrm{~m}$. The seismic profile II - II' was carried out in the A2 heading at a depth of about $850 \mathrm{~m}$. Both seismic profiles were located in the impact zone of the overlying edge of the X2 coal seam, lying about $40 \mathrm{~m}$ above the X0 coal seam. Both the seismic profiles were $135 \mathrm{~m}$ long.

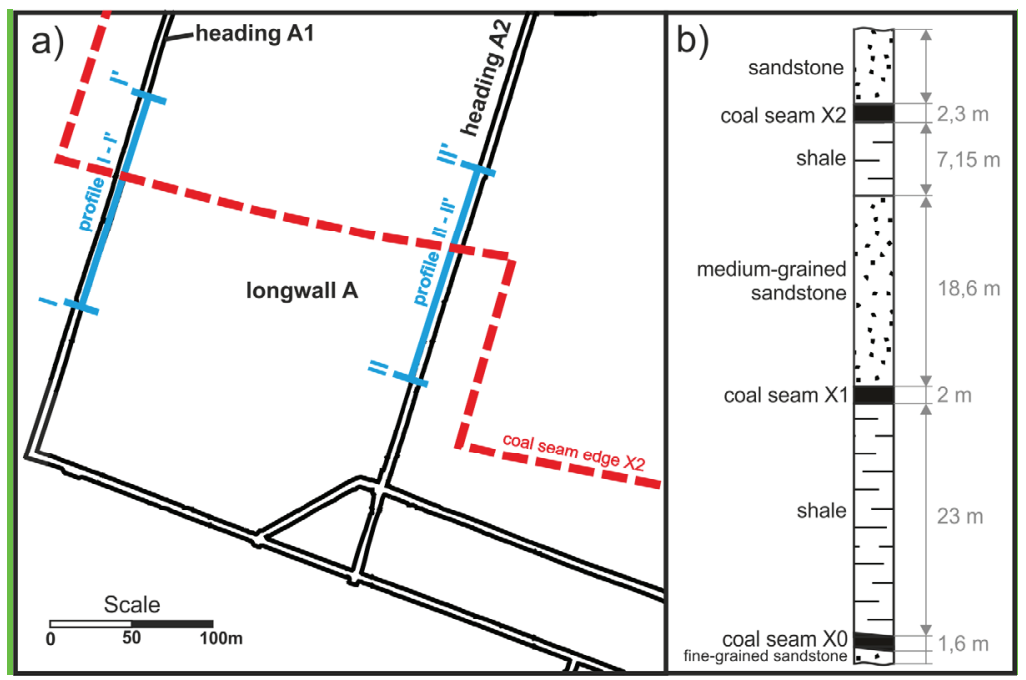

Fig. 5. (a) Location of the seismic profiles in the region of the A longwall in the X0 coal seam, with the edge of the X2 coal seam indicated; (b) geological profile from the region of the A longwall.

In the research area, the X0 coal seam has a mean thickness of about $1.60 \mathrm{~m}$ (Figure $5 \mathrm{~b}$ ). The slope of the seam is approximately $6^{\circ} \mathrm{NW}$. A shale layer of $23 \mathrm{~m}$ in thickness occurs as the immediate roof of the X0 seam. A medium-grained sandstone layer of $18.6 \mathrm{~m}$ in thickness and a layer of shale of $7.15 \mathrm{~m}$ in thickness occur above the X1 coal seam. Coal seam X2 is located approximately $40 \mathrm{~m}$ above seam X0. A fine sandstone layer of $18.6 \mathrm{~m}$ in thickness occurs below the X0 coal seam.

\section{Results and analysis}

A diagram of the changes of refracted P-wave velocity on both profiles I - I' and II - II' in a region of the A longwall in the X0 coal-seam is presented on Fig. 6 . The error of the measured velocity did not exceed $50 \mathrm{~m} / \mathrm{s}$ and the velocity differences on both profiles were greater than the measurement error. 


\subsection{Profile I- I'}

Throughout the entire length of the profile I - I', the P-wave velocity varies from $2180 \mathrm{~m} / \mathrm{s}$ to $2320 \mathrm{~m} / \mathrm{s}$. On the basis of velocity changes, two sections can be distinguished: first from 0 to about $90 \mathrm{~m}$, second from about 90 to $135 \mathrm{~m}$ of the profile length. In the first section, the velocity of the P-wave changes from $2220 \mathrm{~m} / \mathrm{s}$ to $2320 \mathrm{~m} / \mathrm{s}$. The maximum velocity occurs at about $80 \mathrm{~m}$. The calculated anomaly equal to $\mathrm{A} 1=7.8 \%$ for a reference velocity of 2140 $\mathrm{m} / \mathrm{s}$. The level of the anomaly indicates a low increase of relative stress between $20 \%$ and $60 \%$. The influence range of this anomaly is estimated to be from about $68 \mathrm{~m}$ to $90 \mathrm{~m}$. Assuming that on the initial section of the profile, measured wave velocities $\mathrm{P}$ are not disturbed by an edge influence and other geological and mining factors, it can be assumed that the measured reference velocity is $2220 \mathrm{~m} / \mathrm{s}$. With respect to this velocity, the anomaly A1' is equal to $4.3 \%$, which corresponds to a very low increase in relative stress up to $20 \%$.
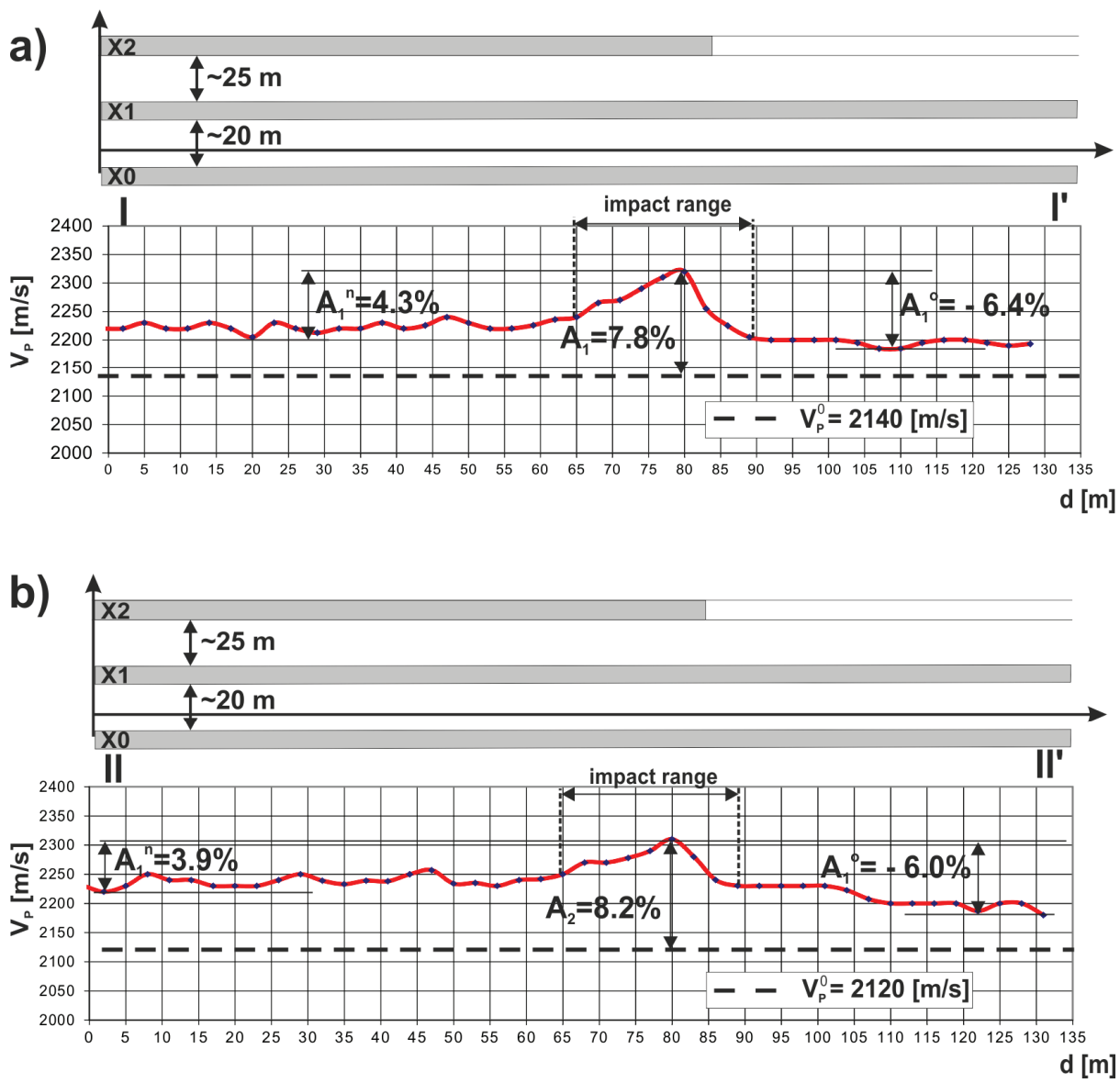

Fig. 6. Changes of refracted $\mathrm{P}$-wave velocity in the $\mathrm{X} 0$ coal seam in the influence zone of the overlying edge in the X2 coal seam: a) seismic profile I - I' in drift A1, b) seismic profile II - II' in drift A2.

The value of anomaly A1', according to the assumption of the Dubinski classification, seems to be more probable than the anomaly A1, because it was calculated from the measurement data. The results indicate a low impact of the edge of the X2 coal seam on the $\mathrm{X} 0$ coal seam in the heading A1. 
On the second section of the profile I - I' under the gobs of the X2 coal seam, the P-wave velocity varies from 2180 to $2230 \mathrm{~m} / \mathrm{s}$. The smaller P-wave velocity compared to the first section indicates the destressing impact of the gobs of the X2 coal seam. However, the destressing impact of these gobs is small, because the calculated anomaly compared to the maximum velocity value of $2320 \mathrm{~m} / \mathrm{s}$ is equal to A1" $=-6.4 \%$. The small destressing impact of the gobs of the X2 coal seam corresponds to the small increase of relative stresses induced by the edge of X2 coal seam.

\subsection{Profile II- II'}

On the profile II - II', the P-wave velocity varies from $2180 \mathrm{~m} / \mathrm{s}$ to $2320 \mathrm{~m} / \mathrm{s}$, which is similar to profile I - I'. On the basis of the velocity changes, two sections can be distinguished: first from 0 to about $90 \mathrm{~m}$, second from about 90 to $135 \mathrm{~m}$ of the profile length. In the first section, the velocity of the P-wave changes from $2220 \mathrm{~m} / \mathrm{s}$ to $2310 \mathrm{~m} / \mathrm{s}$. The maximum velocity occurs at about $80 \mathrm{~m}$. The calculated anomaly is equal to $\mathrm{A} 2=8.2 \%$ for a reference velocity of 2120 $\mathrm{m} / \mathrm{s}$. The level of the anomaly indicates a low increase of relative stress of between $20 \%$ and $60 \%$. The influence range of this anomaly is estimated to be from about $72 \mathrm{~m}$ to $97 \mathrm{~m}$. Assuming that on the initial section of the profile, measured wave velocities $\mathrm{P}$ are not disturbed by an edge influence and other geological and mining factors, it can be assumed that the measured reference velocity is $2220 \mathrm{~m} / \mathrm{s}$. With respect to this velocity, the anomaly A2' is equal to $3.9 \%$, which corresponds to a very low increase in relative stress up to $20 \%$.

On the second section of the profile II - II' under the gobs of the X2 coal seam, P-wave velocity varies from 2180 to $2230 \mathrm{~m} / \mathrm{s}$, identical to that on profile I - I'. The destressing impact of the gobs of the X2 coal seam is also small, since the calculated anomaly, compared to the maximum velocity value of $2320 \mathrm{~m} / \mathrm{s}$, is equal to $\mathrm{A} 2 "=-6.0 \%$.

The results obtained on both seismic profiles are very similar, which demonstrates the small impact of the edge of X2 coal seam on the X0 coal seam in both headings of the A longwall. The compatibility of the results on both profiles indicates the great repeatability of the seismic profiling surveys. It should be underlined that, at greater exploitation depths, the calculated reference velocity is less reliable than the measured reference velocity.

\section{Conclusions}

Under the conditions of multi-seam exploitation in underground coal mines, excavations are often located in the zone of excessive impact of various types of edges and remnants of unexploited coal seams. Seismic profiling is one of the fundamental methods, which allow the assessment of such impacts directly in the hazard zone. On the basis of the results of seismic profiling presented in the paper, the following conclusions can be formulated:

1. Seismic profiling provides reliable information about $\mathrm{P}$-wave velocity changes in the coal seam along the side-wall of the excavation. The results of surveys conducted in two different impact zones of the same edge of a coal seam presented similar values of refracted P-wave velocity and calculated seismic anomaly.

2. At greater depths, the calculated reference velocity may vary from the measured velocity. For the calculation of the anomaly, measured velocity can give more valuable information.

3. In Polish hard coal mines exploitation takes place at increasingly greater depths, even below $1300 \mathrm{~m}$. The method of calculating a seismic anomaly can be presumed to require updating under such conditions. To achieve this goal, more experimental results should be obtained. 


\section{References}

1. Z. Burtan, The influence of natural hazards on occupational safety in Polish collieries, Proc. of Int. Mining Forum on mine safety and efficient exploitation facing challenges of the $21^{\text {st }}$ century, $81-90$ (2010)

2. Z. Burtan, Z. Rak, J. Stasica, Priorities in the development of mining systems in the mining sector in Poland, Gospod. Surowcami Min. 24, 1, 185-200 (2008)

3. J. Dubiński, W. Konopko, Tapania - ocena, prognoza, zwalczanie (Wydawnictwo GIG, Katowice, 2000)

4. J. Dubiński, Z. Pilecki, W. Zuberek, Badania geofizyczne w kopalniach-przeszłość, teraźniejszość, i zamierzenia przyszłość (IGSMiE PAN, Kraków 2001)

5. M. Kwaśniewski, J. Wang, Numerical analysis of mining-induced deformations of the strata, Proc. of The School of Underground Mining '96, 153-187 (in Polish) (Centrum PPGSMiE PAN, Kraków 1996)

6. Z. Pilecki, Modelowanie numeryczne pola naprężenia $w$ górotworze naruszonym wielopokładowa eksploatacja węgla kamiennego $w$ warunkach silnego zagrożenia sejsmicznego, Zeszyty Naukowe - Bulletin of the Mineral and Energy Economy Research Institute of the Polish Academy of Sciences 80, 93-102 (2011)

7. J. Dubiński, K. Stec, Relationship between focal mechanism parameters of mine tremors and local strata tectonics, Proc. of the 5th International Symposium on Rockbursts and Seismicity in Mines (January 2001)

8. Z. Burtan, A. Zorychta, J. Cieślik, D. Chlebowski D., Arch. Min. Sci. 59, 3, 691 - 704 (2014) doi: 10.2478/amsc-2014-0048

9. J. Dubiński, Sejsmiczna metoda wyprzedzajacej oceny zagrożenia wstrzasami górniczymi w kopalniach węla kamiennego (Prace GIG, Seria dodatkowa, Katowice 1989)

10. B.H.G. Brady, E.T. Brown, Rock mechanics for underground mining, (University Press, Cambridge 1993)

A. Kidybiński, Podstawy geotechniki kopalnianej (Katowice 1982)

11. R. Czarny, H. Marcak, N. Nakata, Z. Pilecki, Z. Isakow, Pure Appl. Geophys. 173, 6, 1907-1916 (2016) doi: 10.1007/s00024-015-1234-3.

12. E. Hoek, P.K. Kaiser, W.F. Bawden, Support of underground excavations in hard rock (1995)

A. Tajduś, M. Cała, K. Tajduś, Studia Geotechnica et Mechanica 38, 1, 109 - 121 (2016) doi: $10.1515 /$ sgem-2016-0012

13. Z. Pilecki, Metoda oceny zachowania się masywu skalnego wokót wyrobiska podziemnego, Studia, Rozprawy, Monografie 59 (IGSMiE PAN, Kraków 1999)

14. Z. Pilecki, Dynamic analysis of mining tremor impact on excavation, Proc. Int. FLAC Symp. on Numerical Modeling in Geomechanics, Detournay \& Hart, 397-400 (Minneapollis, USA 1-3 Sept. 1999)

15. Z. Pilecki, G. Mutke, Oddziatywanie wstrząsu górniczego w strefie bliskiego pola falowego na wyrobisko chodnikowe - analiza numeryczna, Mat. X Międzyn. Konf. Tąpania, Główny Instytut Górnictwa, 223-232 (Ustroń, 12-14 Nov. 2003)

16. Z. Szreder, Z. Pilecki, J. Kłosiński, Effectiveness of recognition of exploitation edge influence with the help of profiling of attenuation and velocity of seismic wave, Gospod. Surowcami Min. 24, 2, 215-226 (2008)

17. Ł. Wojtecki, Wykorzystanie metod sejsmicznych w wersji kinematycznej do określania stanu naprężeń w górotworze podczas eksploatacji w Kopalni Węgla Kamiennego „Bielszowice”, 578-597 (Prace Naukowe GIG, Górnicze Zagrożenia Naturalne, Katowice, 2011) 
18. Ł. Wojtecki, G. Dzik, Profilowanie sejsmiczne ociosów chodników węglowych w wersji kinematycznej i ttumieniowej. Mechanizacja i Automatyzacja Górnictwa 50, 4, 29 - 37 (2012)

A. Tor, P. Chmiel, Z. Pilecki, A. Jakubów, R. Skatuła, Z. Szreder, J. Kłosiński, Kontrola efektywności strzelań torpedujacych za pomoca profilowań sejsmicznych, Bezpieczeństwo Pracy i Ochrona Środowiska w Górnictwie, Miesięcznik WUG 142, 6 , 62-64 (2006)

19. Z. Pilecki, Z. Szreder, Możliwości wykorzystania współczynnika tłumienia do oceny stanu naprężenia i deformacji za pomoca profilowań sejsmicznych $w$ warunkach dużych głębokości, Prace Naukowe GIG 4, 197-203 (2007)

20. Z. Szreder, Z. Pilecki, J. Kłosiński, Comparison of Profiling Results of Attenuation and Velocity of Refracted P-wave in Coal-seam, Proc. 14th European Meeting of Environmental and Engineering Geophysics, EAGE (Krakow 15-17 September 2008)

21. J. Ślizowski, Z. Pilecki, K. Urbańczyk, E. Pilecka, L. Lankof, R. Czarny, Adv. High Energy Phys., 1-12 (2013) doi: 10.1155/2013/461764

22. Z. Majcherczyk, Z. Pilecki, E. Niedbalski, E. Pilecka, M. Blajer, J. Pszonka, Wpływ warunków geologiczno-inżynierskich i geotechnicznych na dobór parametrów obudowy wstepnej tunelu drogowego w Lalikach, Gospod. Surowcami Min. 28, 1, 103-124 (2012)

23. B. Ladanyi, Use of the long-term strength concept in the determination of ground pressure on tunnel linings, Proc. of the Third Congress of the Int. Soc. for Rock Mech., II, B, 1150-1156 (Denver, 1974) 